\title{
Fecal Sludge Management Technologies: Comparing the Opportunities and Challenges
}

\author{
Jheelam Sarkar and Rajarshi Banerjee* \\ Chadwick's FSM Laboratory, Banka BioLoo Limited, 56. Nagarjuna Hills Road, Punjagutta, \\ Hyderabad- 500082, India \\ *Corresponding author
}

\section{A B S T R A C T}

\section{Keywords}

Fecal Sludge, Sanitation Value Chain, Open Defecation, Treatment, Reuse

Article Info

Accepted: 12 March 2021 Available Online: 10 April 2021
Fecal sludge (FS) and septage is an assimilation of excreted night soil and black water. Primarily being a human waste, FS constitutes enormous genera of microbes, opportunistic pathogens, and parasitic cysts. The World Bank data revealed it has a potent to cause about a lakh of diarrheal decease every annum in India within the age group of zero to five. With the catastrophic consequences, mismanagement of fecal sludge is undoubtedly a hazard to wholesome sanitation. Since all 28 states and 8 union territories of India have been declared open defecation free (ODF) on October 2019 , presently the nation is keen to augment the individual components attributed to the sanitation value chain. Initiating from decanting to scientific management, and final disposal/reuse on each stage noteworthy contribution recorded either in terms of technical interventions or engaging stakeholders. As per the depository of the Ministry of Housing and Urban Affairs (MoHUA), presently 819 cities in the country are already compliant and certified under ODF+ protocol of which totally 312 cities are further accredited with $\mathrm{ODF}++$ tag for ensuring zero discharge of untreated sludge. Hitherto, different ranges of conventional and mechanized treatments have been explored for pertinent handling and management of FS with same the primary agenda of eased solid-liquid separation. It is highly difficult to opt for a single mechanism that is ample to cater all the requisites and economic, rather the management of FS is more case specific. The review of several FS management technologies has ultimately aided in developing an affirmative understanding that geotextile-based technologies have genuinely an upper hand within limited capacities, while mechanization is a mandate for large-scale centralized management.

\section{Introduction}

Fecal sludge (FS) is a mixture of human excreta, water and solid wastes (e.g. toilet paper or other anal cleansing materials, menstrual hygiene materials) that are disposed of in pits, tanks or vaults of the onsite sanitation systems ${ }^{[4]}$. It is an unpleasant material containing pathogens, generating odours and causing surface water and groundwater pollution as well. Septage/ Fecal sludge is basically, raw or partially digested 
slurry or semisolid form of excreta. It is the collection (of excreta, black water, grey water), storage or treatment combinations that constitute Fecal Sludge Management. Such FS are generally a few times more concentrated in suspended and dissolved solids when compared to domestic wastewater ${ }^{[20]}$. Fecal Sludge Management (FSM) is a settlement, where the fecal sludge collection, transport, and treatment from pit latrines, septic tanks or other onsite sanitation systems (OSS) are followed.

More necessarily robust sanitation and quality hygiene is a mandate in the urban and rural areas. Maximum of us are progressively living in the urban areas - accounting almost $52 \%$ of the world population approximately; 3.8 billion people to be precise. The developing countries are experiencing a runaway urban population growth, with a major chunk living in slums without access to any basic sanitation amenities, only making the problem further rampant, severe, and challenging ${ }^{[1]}$.Although with rapid population growth due to modernization, the density of rural population also imposes a similar challenge.

Since, the most conventionally approached solution for urban sanitation is piped sewerage with centralized wastewater treatment; likewise, many of the engineers, city managers and politicians regard it as the only authorized solution. Networked sewerage system is accessible to mostly the better-off, while the poor people are the ones left to fend for them. They improvise on-site systems, which are also shared with other families, which might be illegal under the local by-laws ${ }^{[1]}$. So, they basically use non-networked sanitation, which includes the excreta and wastewater discharged into a septic tank or pit, or directly discharged into the environment. Those with further affordability issues are left to defecate in the open or into a plastic bag. Once the pits and tanks are filled up, they are often emptied by informal, unhygienic and undignified methods (manual), with the fecal sludge being buried or dumped openly. The result in such cases is chronic outbreaks of cholera and other enteric infections, which affect the whole residence $^{[14]}$.

Thus, FSM is mostly necessary in the densely populated areas where a segment of the population is not connected to a sewerage network, and where the overlaying and remodeling of the pit latrines is not possible [20]. This primarily prevails in the developing countries, mostly in the urban areas; but the developed countries also use such services, specifically where sewerage systems are unavailable. In Uganda, around $46 \%$ of excreta, in Tanzania $57 \%$ of excreta, in Kenya $64 \%$ and in Indonesia more than $80 \%$ of excreta are left untreated ${ }^{[5]}$. In Sub-Saharan Africa, $65-100 \%$ of access to sanitation in the urban areas is provided through onsite technologies ${ }^{[22]}$. These services are mostly endowed by the local governments, water authorities, formal and informal service providers in the private sector etc. However, in many of the developing countries FSM services are often unavailable, or even if they are available, are often informal, unregulated, unhygienic or unsafe; which can lead to the pollution of surface water and groundwater along with spreading of pathogens into the environment. Such services hurl adverse impacts on public health; not only for those with limited sanitation, but for others as well [20].

\section{Fecal Sludge Management in India}

One of the major challenges in urban sanitation sector is the collection, treatment and disposal or reuse of Faecal Sludge. Adequate amenities and services for collection, transportation, treatment and disposal of Faecal sludge do not exist in most Indian cities and towns. In the absence of such 
facilities, most of the on-site sanitation systems are emptied manually. As per the Central Public Health and Environmental Engineering Organization (CPHEEO) guidelines, preferably, a septic tank system should be cleaned in every one and half to three years ${ }^{[18]}$. However, ignorance of maintenance and operational conditions usually results in accumulation of organic sludge, reduction in effective volume and hydraulic overloading, which ultimately causes system failure and the release of partially treated or untreated septage from the septic tank. Private operators often do not transport and dispose of septage far away from human settlements; instead, they dump it in drains, waterways, open lands, and agricultural fields ${ }^{[2]}$.

India has witnessed revolutionary changes towards it's voyage of becoming an Open Defecation Free (ODF) country since the Swachh Bharat Mission (SBM) materialized, bringing several corporates, NGOs, and government working for the cause of a clean India together. Motivated by the joint resolution of SBM, various other such initiatives also came to the forefront to hold the reign of sanitation and make India a safe and healthy country to live ${ }^{[3]}$. Swachh Bharat Mission (SBM), Swachh Bharat Abhiyan or Clean India Mission is a country-wide campaign established by the Government of India in 2014 to eliminate open defecation and improve Solid Waste Management (SWM).The India Sanitation Coalition was launched on June 25, 2015, in order to escort various stakeholders, who care for the country's sanitation and hygiene to one single platform. The Ministry of Housing and Urban Affairs (MoHUA) is working towards ensuring sustainability of the ODF status to ensure proper maintenance of toilet facilities, hereby referred to as $\mathrm{SBM} \mathrm{ODF+,} \mathrm{and} \mathrm{safe}$ collection, conveyance, treatment and disposal of all fecal sludge and sewage, hereby referred to as SBM ODF++, to the cities and towns that have already achieved Open Defecation Free (ODF) status as per the ODF protocol, in order to achieve safe sustainable sanitation for all. The SBM ODF+ and SBM ODF++ protocols are incremental in nature, and reflect on-ground realities present in India ${ }^{[9]}$.

Under the Swachh Bharat Mission (SBM), it is predicted that nearly $80 \%$ of the 7.90 million household $(\mathrm{HH})$ (or nearly 6.3 million $\mathrm{HHs}$ ) will meet their sanitation needs through newly-built individual household toilet (IHHT) and the remaining 20\% (or nearly 1.6 million HHs) will rely on existing or newlybuilt community toilets. India's bigger cities have large, centralized sewerage systems with vast underground pipelines, pumping stations and huge treatment plants, that are expensive to be built and even more expensive to be operated effectively, as they require continuous power, a large amount of water, skilled operators and extensive electromechanical maintenance. This is the reason why India's 7,000+ small towns do not have such systems and are unlikely to be covered by centralized sewerage systems in the near future $^{[11]}$.

The MoUD (Ministry of Urban Development) recognizes that the end objectives and that the corresponding benefits of SBM cannot be achieved without proper management of fecal sludge and septage across the sanitation service chain [13]. Further, it is well acknowledged that sewerage handling will not meet the complete sanitation needs in all areas, and a strategy which is a combination of OSS and off-site (decentralized and centralized) must co-exist in all cities and must be given equal attention. So, to address the gaps and provide necessary directions to diverse stakeholders engaged in provision of FSSM services, the MoUD and a host of research and civil society organizations jointly drafted and signed a National Declaration on 
Faecal sludge and Septage management (FSSM) on 9th September, 2016. This policy addresses the efficiency of systems in place for onsite sanitation whereof the fecal sludge output is supposed to be managed in an environmentally safe manner including the proper engineering design, construction and maintenance of septic tank systems, pit latrines and such other systems generating fecal sludge for further treatment ${ }^{[11]}$.

\section{Overview of Treatment Technologies}

The report of the Census of India 2011 states that only 32.7 per cent of urban households are connected to a piped sewer system whereas 38.2 per cent dispose their wastes into septic tanks and about 7 per cent into pit latrines, emphasizing the predominance of onsite arrangements - and it is not clear how the waste is further disposed by the majority of these installations ${ }^{[2]}$. It also showed that in 4,041 statutory towns, 7.90 million households (HHs) do not have access to toilets and defecate in the open ${ }^{[11]}$. Currently, septic tanks and pit latrines along with open defecation are major contributors to groundwater and surface water pollution in many cities in the country ${ }^{[15]} .2 .7$ billion People worldwide are served by sanitation methods that need fecal sludge management.

The key objective of the urban FSSM Policy is to set the background, priorities, and direction and to facilitate, nationwide implementation of FSSM services in all the ULBs (Urban Local Bodies) such that safe and sustainable sanitation becomes a reality for all in each and every household, street, town, and city ${ }^{[11]}$.

With the increased coverage of toilets across the country under the SBM, it's of utmost importance that the technological interventions for the management of faecal waste- septage and sludge are strategically implemented.
The post-2015 Sustainable Development Goals (SDGs) include the whole sanitation services chain, from toilet, to excreta containment at the household - in a pit or tank or flushed into a sewer - to transport, treatment and disposal ${ }^{[20]}$. The value chain of excreta: containment, emptying, transport, treatment, reuse or disposal, is designed to recover resources and improve sanitation in areas with no centralized sewerage systems in order to contribute to sustainable sanitation services.

The treatment technologies, followed in this strategy are broadly categorized based on the process principles: biological, non-biological, and electro-mechanical systems. Solid-liquid separation being the primary object, the technologies based on the treatment mechanism are grouped under the categories listed in Table $1^{[4]}$.

\section{Fecal Sludge Treatment Technologies}

Since, Indians are predominantly washers, so the septage coming for the treatment processes typically contains $96 \%$ of Water and only $4.0 \%$ of Solid, often biologically stabilized or not stabilized. The fecal sludge coming from the on-site sanitation (OSS) sectors is basically stable, while the sludge coming from holding septic-tanks is unstable. After the extraction of debris and heavies (sand, grit, rocks, glass, and metal) from the incoming sludge, rendering those materials safe for human contact and disposal, the major challenge is achieving optimal solid-liquid separation by dewatering and treating the effluent so that it is safe for disposal or reuse $^{[10]}$.

Thus, the technologies being compared here, mainly focusing on efficacy in segregating water and solid; purifying the water to an extent for reusing or surface disposal; and ensuring that the bio-solid hence acquired, 
undergoes disinfection and removal of pathogens for re-use. The pros and cons of the most prominent available technologies are delineated herein.

\section{Pyrolysis based Operation}

The working principle of pyrolysis is thermochemical decomposition of organic material at elevated temperatures in the presence of controlled oxygen to efficiently convert sludge into bio-char without external power. The system constitutes of grit removal, pasteurization, solid-liquid separation, pyrolyser, heat exchanger and dewatered effluent treatment system. These subsystems consolidated together to form a complete plant that processes faecal sludge to bio-char. The counter flow heat exchanger redeems the heat generated from pyrolysis and is reused back within the system, without the need of any external heat source, enabling sustained operations. The system can be equipped with provisions like online temperature monitoring to optimize the energy consumption. The biochar and pasteurized liquid are the final products from the process ${ }^{[12]}$.

\section{Screw-press based Operation}

Screw-press sludge dewatering is a kind of economic and environmental friendly process. It is a type of sludge extrusion dewatering method following the principle of screw extrusion, through the strong squeezing force generated by the change of screw diameter and screw pitch, and the tiny gap between the floating ring and the fixed ring, to uplift separation of liquid from solid. It is composed of fully automatic control cabinet, flocculation modulation box, sludge thickening and dewatering device, and liquid collection tank. This dewatering process is an automatic control technology, which continuously complete the sludge thickening and squeezing, finally returning or discharging the collected filtrate liquid $^{[19]}$. The separated liquid is further processed for secondary treatment; purification like pressure filters (dual media silica and activated carbon respectively), followed by a disinfection process which could be either chlorination or ozonation etc. The separated solids could further be processed for agricultural purposes.

\section{Belt-filter Press based Operation}

The belt filter (sometimes called a belt press filter, or belt filter press) technology is used for solid and liquid separation, particularly the dewatering of sludge in the water treatment. This process of solid-liquid separation is primarily attained by passing the influent sludge through a pair of filtering clothes and a belt assembly, which is driven by compacting rollers. The system takes sludge or slurry as a feed, and separates it into a filtrate and a solid cake.It is important to ensure uniform sludge distribution over the belt width, as, increasing the belt speed may lead to a reduction in the sludge dewatering degree ${ }^{[17]}$. Dewatering objectives include reducing the volume, as such to reduce the transport and handling costs; removing liquids before landfill disposal, to minimize the waste management expenditure; reducing fuel requirements before further drying or incineration, producing adequate material for composting; avoiding runoff and pooling when used for land applications; and optimizing other drying processes. The water is additionally pressed out from the already formed cake and subjected to filtration for further use; and the solid could be recycled for various other purposes ${ }^{[17] \text {. }}$

\section{Hydraulic Piston Press and MBBR}

Hydraulic Piston Press is a mechanized process in which solid-liquid separation (dewatering) takes place followed moving bed biofilm bio reactor (MBBR) process for 
further treatment of the liquid part. The separated liquid treatment from MBBR, is channeled to tube settler followed by sand and carbon filter (pressurized filter has sequential dual media silica and activated carbon respectively) and chlorine dosing in the end.

The solid handling is usually through stabilization, belt press, rotatory dryer etc. The tumbling process in rotatory drier sets even distribution of heat in the solids and evaporates the bound water. The treated water can be used for landscaping or agricultural purposes and the dried sludge can be used as manure $^{[12]}$.

\section{Decentralized Waste water Treatment System (DEWATS)}

DEWATS is natural aerobic and anaerobic stabilization of the waste by escalated contact time with the active biomass followed by treatment of both remaining sludge and effluent. The solid handling is generally through Stabilization reactor, Sludge Drying Bed and for liquid treatment Anaerobic Baffled Reactor (ABR) with filter chambers accompanied by Planted Gravel Filter is preferred.

The ABR is typically a five chambered anoxic treatment system, facilitates settling and anaerobic degradation of the organic impurities. The same is believed to be $50-$ $60 \%$ effective in removing organic impurities contributing BOD and COD load ${ }^{[1]}$.

The dried sludge is further used as compost and the entire process is a biological treatment system with no chemicals used. This mechanism is primarily designed as gravitybased system with low electromechanical interventions, majorly making use of the local topography. The products from the process are treated liquid and bio solids/ compost and biogas as eco-friendly fuel ${ }^{[12]}$.

\section{Planted Drying Beds (PDBs)}

The treatment of sludge in PDBs is achieved through a combination of physical and biochemical processes ${ }^{[20]}$. This is a biological system with the coalescence of sludge treatment and liquid treatment by the natural process. Planted drying bed is an upgradation of unplanted drying bed, but has the added advantage of transpiration and enhanced sludge treatment due to the plants. After each feeding or drying cycle, the filters do not need to be de-sludged. The liquid is substantially treated in plated gravel filter. The end to end system comprises planted drying beds for solid and liquid separation, planted gravel filter and polishing pond for liquid treatment along with gravity-based system, depending on natural treatment with no use of chemicals or electricity $^{[15]}$.

\section{Soil Biotechnology}

Soil biotechnology (SBT) is an earthly system for wastewater treatment based on the principle of trickling filter. SBT involves three fundamental processes of naturephotosynthesis, respiration and mineral weathering. Appropriate mineral constitution, culture containing native micro flora and bioindicator plants are the key components of the system. It comprises raw water tank, bioreactor containment, treated water tank, piping and pumps. First the water passes through the additive layer and subsequently passes through the media. The operation can be run as single stage or multistage, depending on the water quality desired. Recirculation is offered for further polishing if needed ${ }^{[4]}$.

\section{Phytorid Wastewater Treatment Technology}

The Phytorid technology involves constructed wetland mechanism based on specific plants, such as elephant grass (Pennisetum 
purpurem), cattails (Typha sp.), reeds (Phragmitessp.), Cannas pp. and yellow flag iris (Iris pseudocorus), duckweed, vetiver grass normally found in natural wetlands with filtration and treatment capability. The phytorid technology treatment system is a subsurface flow-type constructed wetland system with a cell that has baffles in which wastewater is applied to the cell/system filled with porous media such as crushed bricks, gravel and stones, and the hydraulics is taken care of in such a manner that wastewater does not rise to the surface retaining a free board at the top of the filled media ${ }^{[4]}$. The process works on the principles of sedimentation, bacterial action, filtration, adsorption, precipitation and decomposition.

\section{Geotube Treatment Technology}

The Geo bag or tube (basically nonmechanical) technology is used to dry the fecal sludge from on-site sanitation sector (OSS) and is suitable for decentralized fecal sludge treatment. Geo bags are distinguished and made with permeable geo fabrics which have the potential to dewater sludge. Fecal sludge is transferred to these geo tubes/bags from the tankers, after separating the unwanted materials (like plastics, rocks, glass, and metal) from the incoming sludge, and using an organic flocculent to maximize the formation of floc, hence allowing for the filtration and thereby dewatering ${ }^{[5]}$. The effluent from the geo bags is assembled through underground channels and sent for treatment in packaged sewage treatment plant (PSTP).After few days when the solid retaining capacity of the geo bag has reached (depending upon size), the sludge is allowed to be self-composted within the containment. Post-composting bio-solids are cured for a couple of days, checked for pathogen absence, pulverized, packed, and distributed to be used as soil conditioner. This new and innovative technology is also economically viable in comparison to other sludge-dewatering technologies ${ }^{[21]}$.

The salient features of the Geotube treatment are:

Frequent maintenance of the equipment is not needed, as it is a passive technique.

Not labor intensive.

Minimum energy requirement.

Semi-permeable nature of the fabric does not allow water inflow and thereby ensures zero atmospheric interference.

The quality of polypropylene used to make the geo-bag, ensures recyclability.

It can easily handle any shock load or dry flow without compromising the efficacy.

The permeate is filtered water, of a quality that can be re-used/diluted, with or without additional treatment.

\section{Operational Advantages and Disadvantages of the Fecal Sludge Treatment Technologies}

Every technology has some or the other pros and cons. For instance, some consume more energy for the process to run (automated electro-mechanical), whereas, the others (biological) require less energy to operate. Similarly, some need more man power and some requires fewer administrative interventions. While, some have lower operation and maintenance cost, some have higher cost in this sector. In some technologies, pasteurization is easier, and in some cases, further treatment is needed for higher degree of pathogen removal. The advantages and challenges faced in the abovementioned fecal sludge treatment technologies, are detailed out in Table $2^{[12,21]}$. 


\section{Cost Analysis of the Fecal Sludge Treatment Technologies}

Selection of FSTPs for rapid roll-out is possible with a costing standard across all the available technologies over time. This cost assessment here includes CapEx (Capital expenditures) and OpEx (Operational expenditures). Further, assessment of successfully developed models of STPs would strengthen in defining the suitable contracting model for FSTPs, with the cost implications of different technologies over time ${ }^{[12,7]}$

The cost analysis in terms of CapEx and OpEx, for each of the mentioned technologies is provided in Table $3^{[7,16]}$.

These parameters strongly influence the decision-making about the selection of the appropriate fecal sludge treatment technology. The selection of a FS treatment technology for a city also depends on the local conditions and priorities of the region with respect to sanitation such as population coverage, environmental and health benefits, elimination of open defecation, etc. [21]. Extent of treatment has a significant influence on the cost of FSTPs.

The prices mentioned here, are tentative, based on our personal experiences as well as the opinions shared by the other FSM solution providers. So, these are just indicative costs that basically depend on the location of the plant (urban/rural), topology, meteorological characteristics etc. Hence, the prices may vary at times, as such, for additional efforts to ensure safe management of faecal solids, there might be a $30 \%-40 \%$ increase or decrease in the initial CapEx. The OpEx also significantly hikes or dips depending on the location and topology.

\section{Co-treatment of Faecal Sludge}

Co-treatment is the treatment of the raw faecal sludge with sewage or treatment of the effluent from faecal sludge treatment technologies that typically requires further polishing before it is discharged into the water bodies or reused. So, basically this is a treatment method of faecal sludge and septage in Sewage Treatment Plants (STPs) with pretreatment facilities for faecal sludge ${ }^{[10]}$.

Especially in urban India, since, independent FSTP establishment has a space constraint, the combined treatment of FS and wastewater has been thought to be a feasible option with the existing FSTPs.

In addition, the unrestricted dumping of FS into sewers needs to be carefully regulated and prevented. The considerably higher solid content of FS may lead to serious operational problems such as solids deposition and clogging of the sewer pipes, which is mostly because the diameter and slope of the sewers are designed for transport of municipal wastewater. Hence, the primary step in designing a co-treatment system includes the determination of how the FS will be transported to the treatment facility and discharged into the influent stream ${ }^{[20]}$.

The different technologies, followed for cotreatment of faecal sludge are: waste stabilization ponds, anaerobic baffled reactors, constructed wetlands (also called planted gravel filters), planted drying beds, and anaerobic filters ${ }^{[6,23]}$. The effluent can be treated with or without wastewater, while the raw faecal sludge treatment requires a decanting station just before it enters an MBBR or any other electromechanical based technology. 
Table.1 List of Fecal Sludge Treatment Technologies

\begin{tabular}{|c|c|c|c|}
\hline S. No. & Electro-mechanical & Biological & Others \\
\hline $\mathbf{1 .}$ & Pyrolysis & DEWATS & $\begin{array}{c}\text { Geo-tube Treatment } \\
\text { Technology }\end{array}$ \\
\hline $\mathbf{2 .}$ & Screw-press Technology & Planted Drying Beds & \\
\hline $\mathbf{3 .}$ & Belt-filter Technology & Soil Biotechnology & \\
\hline $\mathbf{4 .}$ & $\begin{array}{c}\text { Mechanized De-watering and } \\
\text { MBBR }\end{array}$ & $\begin{array}{c}\text { Phytorid Wastewater } \\
\text { Treatment Technology }\end{array}$ & \\
\hline
\end{tabular}

Table.2 Operational Pros and Cons of the Treatment Technologies

\begin{tabular}{|c|c|c|c|}
\hline Type & Technology & Advantages & Disadvantages \\
\hline \multirow[t]{4}{*}{$\begin{array}{l}\text { Electro- } \\
\text { Mechanical }\end{array}$} & $\begin{array}{l}\text { Pyrolysis based } \\
\text { operation }\end{array}$ & $\begin{array}{l}\text { Automated system having no } \\
\text { direct contact with fecal sludge. } \\
\text { Energy consumption is monitored } \\
\text { Suitable for all weather } \\
\text { conditions. } \\
\text { Bio-safe treatment process for } \\
\text { solids and liquids. } \\
\text { Modular and scalable. } \\
\text { Fast deployment, with very low } \\
\text { footprint. }\end{array}$ & $\begin{array}{l}\text { Requires Electricity (Grid / } \\
\text { DG) and skilled manpower. } \\
\text { External thermal energy } \\
\text { needs depend on varied } \\
\text { septage characteristics, }\end{array}$ \\
\hline & $\begin{array}{l}\text { Screw-press based } \\
\text { operation }\end{array}$ & $\begin{array}{l}\text { Simple design and continuous } \\
\text { operation. } \\
\text { Excellent capture rate. } \\
\text { Designed to feed material that has } \\
\text { a } 40-60 \% \text { water make up. }\end{array}$ & $\begin{array}{l}\text { Capture rate varies per sludge } \\
\text { quality. } \\
\text { Maintenance is hectic. }\end{array}$ \\
\hline & Belt Filter Technology & $\begin{array}{l}\text { Continuous operation. } \\
\text { Easy maintenance. }\end{array}$ & $\begin{array}{l}\text { Relatively higher energy } \\
\text { requirement. }\end{array}$ \\
\hline & $\begin{array}{l}\text { Hydraulic piston press } \\
\text { and MBBR }\end{array}$ & $\begin{array}{l}\text { The process outputs are } \\
\text { completely bio-safe for use } \\
\text { Treatment technology is simple. }\end{array}$ & $\begin{array}{l}\text { Require highly skilled staff } \\
\text { for operations. } \\
\text { No end to end solution. } \\
\text { Mostly liquid fraction treated } \\
\text { and solid part is not given } \\
\text { attention. }\end{array}$ \\
\hline \multirow[t]{2}{*}{ Biological } & DEWATS & $\begin{array}{l}\text { Low operation and maintenance } \\
\text { cost. } \\
\text { Allows for safe operations as no } \\
\text { direct contact with fecal sludge. } \\
\text { Operates without skilled human } \\
\text { resource. }\end{array}$ & $\begin{array}{l}\text { Sludge handling requires } \\
\text { space. } \\
\text { Further treatment of solids } \\
\text { required for higher degree of } \\
\text { pathogen removal. }\end{array}$ \\
\hline & Planted Drying Beds & $\begin{array}{l}\text { Technology is robust and flexible } \\
\text { for extreme conditions. } \\
\text { No direct human contact with }\end{array}$ & $\begin{array}{l}\text { Rate of biological } \\
\text { degradation during extreme } \\
\text { cold weather takes longer }\end{array}$ \\
\hline
\end{tabular}




\begin{tabular}{|c|c|c|c|}
\hline & & $\begin{array}{l}\text { fecal sludge. } \\
\text { Minimal odour during the process } \\
\text { and aesthetically designed to } \\
\text { locate near habitation. } \\
\text { Gravity based system with natural } \\
\text { and biological treatment having } \\
\text { no use of chemicals or electricity. } \\
\text { Simple operations, can be } \\
\text { handled with unskilled operators } \\
\text { and labor. }\end{array}$ & $\begin{array}{l}\text { treatment time. } \\
\text { Bio-safe character of the } \\
\text { process output needs to be } \\
\text { determined. } \\
\text { Odour and flies may be } \\
\text { noticeable. } \\
\text { High land requirement. }\end{array}$ \\
\hline & Soil Biotechnology & $\begin{array}{l}\text { Process can be run on batch or } \\
\text { continuous mode. } \\
\text { Mechanical aeration is not } \\
\text { required. }\end{array}$ & $\begin{array}{l}\text { Marginally higher capital } \\
\text { requirement. } \\
\text { Bigger land area requirement. }\end{array}$ \\
\hline & $\begin{array}{l}\text { Phytorid Wastewater } \\
\text { Treatment Technology }\end{array}$ & $\begin{array}{l}\text { No bio-sludge formation and } \\
\text { complete water recycling } \\
\text { resulting in reduced water intake. } \\
\text { Unskilled human resource } \\
\text { required to operate. } \\
\text { Low power consumption. }\end{array}$ & $\begin{array}{l}\text { Clogging might occur. } \\
\text { Insufficient treatment. }\end{array}$ \\
\hline Other & $\begin{array}{l}\text { Geo-tube Treatment } \\
\text { Technology }\end{array}$ & $\begin{array}{l}\text { No mechanical/electrical } \\
\text { machineries required, hence low } \\
\text { maintenance. } \\
\text { Space saving and scalable } \\
\text { Skilled manpower not required } \\
\text { Facilitates recycle and reuse of } \\
\text { water } \\
\text { No foul odour and no mosquitoes }\end{array}$ & $\begin{array}{l}\text { Land requirement is higher. } \\
\text { Dried sludge before disposal } \\
\text { must be solar-dried to ensure } \\
\text { pathogen/helminths } \\
\text { eradication. } \\
\text { Reusability is a hindrance. }\end{array}$ \\
\hline
\end{tabular}

Table.3 Cost Analysis of the Treatment Technologies

\begin{tabular}{|c|c|c|}
\hline Technology & CapEx (in Rs. /KLD) & OpEx (in Rs. /KLD) \\
\hline Pyrolysis based operation & $8,00,000$ & $65,000-1,00,000$ \\
\hline $\begin{array}{c}\text { Screw-press based operation } \\
\text { Belt filter press-based } \\
\text { operation }\end{array}$ & $10,00,000$ & $1,10,000$ \\
\hline $\begin{array}{c}\text { Mechanized De-watering and } \\
\text { MBBR }\end{array}$ & $9,00,000-14,00,000$ & $1,00,000-1,20,000$ \\
\hline DEWATS & $4,13,000-8,83,000$ & $1,83,000$ \\
\hline Planted Drying Beds & $4,50,000-14,20,000 *$ & $43,000-60,000$ \\
\hline $\begin{array}{c}\text { Soil Biotechnology } \\
\text { Phytorid Wastewater } \\
\text { Treatment Technology }\end{array}$ & $1,01,000-10,00,000$ & $83,000^{*}$ \\
\hline $\begin{array}{c}\text { Geotube based Technology } \\
\text { *The cost varies as per site and location }\end{array}$ & 55,000 & $1,20,000-1,00,000$ \\
\hline
\end{tabular}


Fig.1 Component-wise Alternatives for Sanitation Value Chain

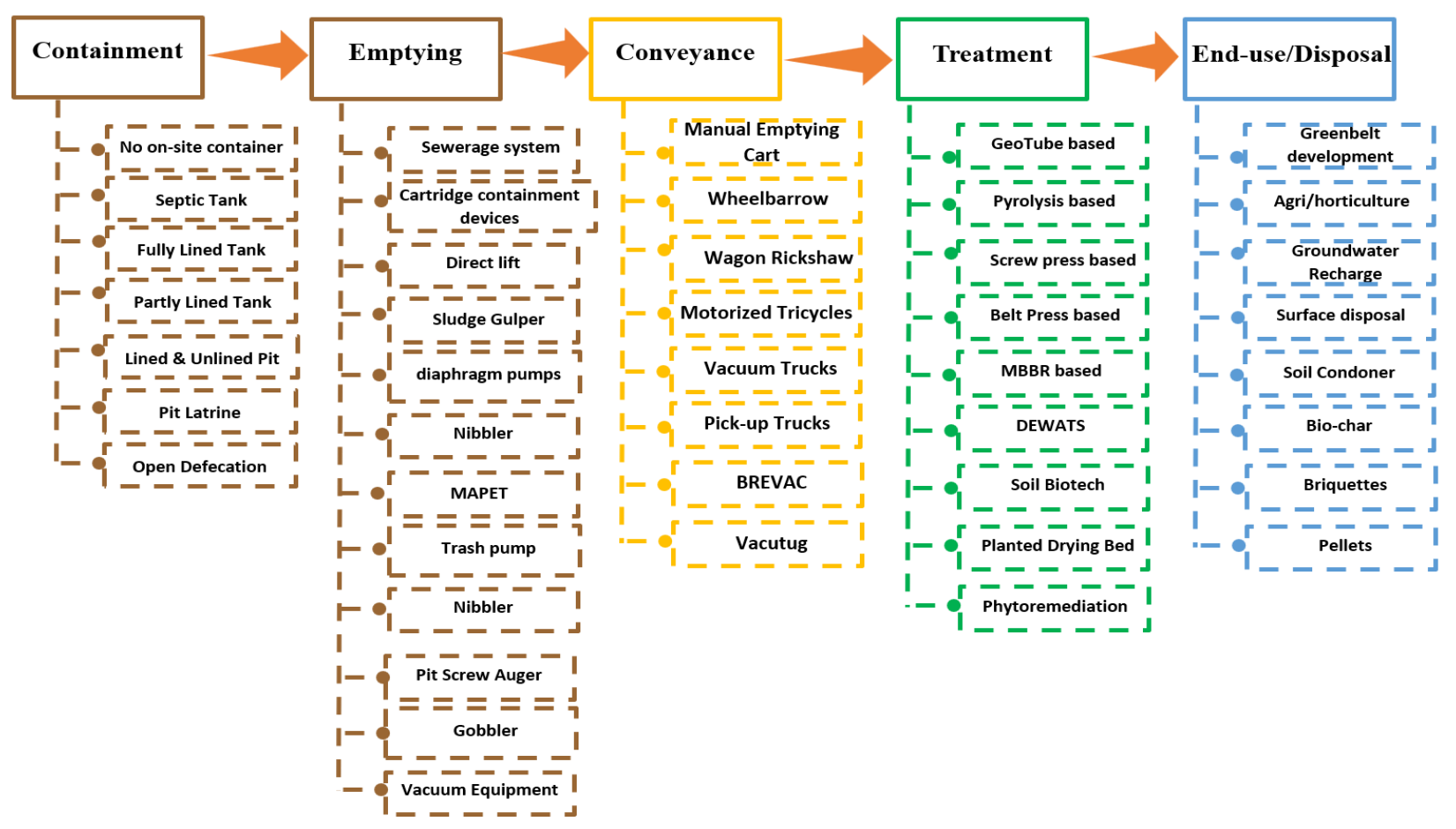

\section{Waste Stabilization Ponds (WSPs)}

Waste Stabilization Ponds are large man-made lined water bodies in which black-water, greywater or faecal sludge are treated by naturally occurring processes. The conversion agents those accelerates the maturation and stabilization are solar curing and disinfection, wind turbulence, inherent microorganisms, and algae.

The ponds can be used individually, or linked in a series for enhanced treatment. There are three types of ponds: anaerobic, facultative, and aerobic (maturation), each with different treatment and designing properties. They have low cost for operation and maintenance and the BOD and pathogen removal is moderate. The effluent consistently contains nutrients (e.g. $\mathrm{N}$ and $\mathrm{P}$ ), even after treatment and is therefore appropriate for reuse in agriculture, but not for direct discharge in surface waters $^{[24]}$.

\section{Anaerobic baffled reactors (ABR)}

Anaerobic baffled reactors are kind of septic tanks, which have been upgraded with a series of baffles along the treatment chamber. The up-flow chambers provide improvised removal and digestion of organic matter. As septic tanks, ABRs are based on a physical treatment called settling and a biological treatment that is the anaerobic digestion ${ }^{[6]}$. An ABR consists of a tank and alternating hanging and standing baffles that provides the reactor with compartments and forces liquid to flow up and down from one compartment to the next, enabling an enhanced contact between the fresh wastewater entering the reactor and the residual sludge, containing the microorganisms, responsible for anaerobic digestion of the organic pollutants. The compartmentalized design distinguishes the solids retention time from the hydraulic retention time, making it possible to anaerobically treat the wastewater at short 
retention times of only some hours. Both the sludge and effluent needs further treatment after the process ${ }^{[24]}$.

\section{Constructed Wetlands}

Constructed wetlands have been widely used in the treatment of primary or secondary domestic sewage effluents and also, have been used to treat domestic wastewater. They have been modeled to handle high organic loads associated with agriculture or domestic wastewater. They are designed and built similar to natural wetlands to treat wastewater, consisting of a shallow depression in the ground with a level bottom. The flow is controlled in constructed wetlands; thus, the water is spread evenly among the plants in there. In natural wetlands, $90 \%$ of the water flows through small channels. Controlling the flow allows natural procedures to occur and clean the wastewater more efficiently ${ }^{[8]}$.Likewise, as discussed earlier, Planted Drying Beds have the benefit of transpiration and enhanced sludge treatment due to the plants. The key improvement is that the filters do not need to be de-sludged after each feeding/drying cycle. The plants and their root systems maintain the porosity of the filter, when fresh sludge is directly applied onto the previous layer ${ }^{[20]}$.

\section{Anaerobic Filter}

An anaerobic filter is a fixed-bed biological reactor having one or more filtration chambers in a series. Particles are trapped and organic matter is degraded by the active biomass that is attached to the surface of the filter material, as wastewater flows through the filter. Pre and primary treatment is necessary to remove solids and garbage that may clog the filter. Most of the settleable solids are removed in a sedimentation chamber in front of the anaerobic filter ${ }^{[23]}$.
Since, the faecal sludge is highly variable in its consistency; quantity and concentration, varying results are obtained from the cotreatment process. Thus, co-treatment plants are designed in such a way, that the existing FSTPs do not get any shock load.

\section{Challenges to Faecal Sludge Management}

There is a plethora of technologies that are existing right now, and every other day, new technologies are emerging for the treatment of faecal sludge. Ultimately, whichever technology is taken up, the efficiency of the process depends on dewatering the sludge water and the solid; purifying the water to a level for reusing or surface disposal; ensuring the disinfection and removal of pathogens from them; and assuring their re-use. So, considering waste as a valuable resource, proper technology implementation is required. Based on the geographical location; prevalent market for the recyclability of the bi-products from the treatment plant would empower the contribution to circular economy in sanitation. Attempts are in process to optimize and scale up resource recovery from such bi-products.

The major challenges faced mainly in the urban areas, while contemplating the installation of a Faecal Sludge Treatment Plant (FSTP) are:

Getting a suitable location for the plant.

Selecting the ideal technology, postconstruction of the FSTP.

Gathering trained human power to run the plant; fourthly, because there are no standards for faecal sludge, so monitoring the evaluation possesses a big challenge. Although it is quite understood by now, that evaluation is not restricted, as FS has a diverse range in its consistency, quantity and concentration. 
Running the plant is a challenge in itself, when it is highly power intensive; like in the case of electro-mechanical based treatment mechanisms.

Changing the habitat and mindset of the people residing nearby, as well as the people working in the FSTP is a tough job.

Managing the de-sludgers, an un-organized sector of workers, to not flush out nonbiodegradable waste from domestic OSS systems, is a huge obstacle in the way. Also, convincing them and properly monitoring them for the easy supply and usage of personal protective equipment (PPE), during their work is quite hectic.

So, overcoming these challenges to establish a Fecal Sludge Treatment Technology is not only about providing the best solution at the lowest price, but also about initiating sustainability, including social and environmental acceptance and institutional feasibility.

\section{References}

Arbogast, B., So, J. November 18, 2013. Why Faecal Sludge Management is Serious Business.

An Assessment of Faecal Sludge Management Policies and Programmes at The National and Select States Level. Report by Water Aid. April 26-27, 2018. India Sanitation Conclave Report.

Banerjee, R., Vinod, V. June 23, 2017. Development and Validation of Protocol for Testing Faecal Sludge and Decentralized Wastewater Technologies.

Banka, N., Mahalakshmi, L., Choudhury, A. R., Sarkar, J., Anandapu, S. C., Banerjee, R., 2020. Evaluation of the Functionality of GeoTube $\AA$ based
Physicochemical Faecal Sludge Treatment: A Cursory Alternate. International Journal of Plant and Environment.

Bachmann, A., Beard, V. L., McCarty, P. L., 1985. Performance Characteristics of the Anaerobic Baffled Reactor. Water Research 19 (1): 99-106.

Cost Analysis of Fecal Sludge Treatment Plants in India. National Institute of Urban Affairs (NIUA). 25 October, 2017.

Declaring your City/Town SBM ODF+ and SBM ODF++ Toolkit for Urban Local Bodies. Ministry of Housing and Urban Affairs (MoHUA), Government of India. December 02, 2015

National Policy on Faecal Sludge and Septage Management (FSSM). Government of India, Ministry of Urban Development. February 2017.

Faecal Sludge Treatment Technologies in India-Compendium. National Institute of Urban Affairs (NIUA).

Guidelines for septage management in Maharashtra. Swachh Maharashtra Mission, Urban Development Department, Government of Maharashtra. 2015.

Hawkins, P., Blackett, I. July 06, 2016. Faecal sludge management is the elephant in the room, but we have developed tools to help.

Ingallinella, A. M., Sanguinetti, G., Koottatep, T., Montangero, A., Strauss, M., 2002. The challenge of faecal sludge management in urban areas strategies, regulations and treatment options. Water Science and Technology, 46, pp 285-294.

June, 2016. Technology Options for the Sanitation Value Chain 1. Center for Study of Science, Technology and Policy (CSTEP)

Kamizela, T., Kowalczyk, M., Sludge dewatering: Processes for enhanced 
performance. Institute of Environmental Czestochowa Technology, Częstochowa, Poland

2013. Manual on Sewerage and Sewage Treatment Systems. Central Public Health and Environmental Engineering Organization (CPHEEO), MoUD.

10 October 2014. PWTech Volute Dewatering Press. Process Wastewater Technologies, LLC. (As viewed on 21 November, 2020).

Strande, L., Ronteltap, M., Brdjanovic, D. Faecal Sludge Management Systems Approach for Implementation and Operation.

Singha, S., Mohana, R. R., Rathi, S., Janardhana R. N., February, 2017. Technology options for faecal sludge management in developing countries: Benefits and revenue from reuse.
Environmental Technology \& Innovation 7.

Strauss, M., Barreiro, W.C., Steiner, M., Mensah, A., Jeuland M., Bolomey, S., Montangero, A., Koné, D., Urban excreta management - situation, challenges, and promising solutions. Department of Water and Sanitation in Developing Countries (SANDEC), Swiss Federal Institute for Environmental Science and Technology (EAWAG)

Sperling, M.V., de Lemos Chernicharo, C.A., 2005. Biological Wastewater Treatment in Warm Climate Regions, Volume One. IWA Publishing, London, UK. pp. 728-804.

Tilley, E., Ulrich, L., Lüthi, C., Reymond, P., Zurbrügg, C., July 2014. Compendium of Sanitation Systems and Technologies. 2nd Edition.

\section{How to cite this article:}

Jheelam Sarkar and Rajarshi Banerjee. 2021. Fecal Sludge Management Technologies: Comparing the Opportunities and Challenges. Int.J.Curr.Microbiol.App.Sci. 10(04): 136-149. doi: https://doi.org/10.20546/ijcmas.2021.1004.013 